DOI: https://doi.org/10.32839/2304-5809/2021-5-93-33

УДК 614.8:331.45

Куріс Ю.В., Матяшев Д.О.

Запорізький національний університет Матяшева О.Б.

Науково-методичний центр професійно-технічної освіти у Запорізькій області

\title{
ДОСЛІДЖЕННЯ ВПЛИВУ ПАРАМЕТРІВ СВІТЛОВОГО СЕРЕДОВИЩА НА ЗДОРОВ'Я ЛЮДИНИ ВПРОДОВЖ РОБОЧОЇ ЗМІНИ
}

\begin{abstract}
Анотація. У статті досліджено параметри санітарно-гігієнічних фракторів виробничого середовища на робочих місцях постійного перебування робітників у процесі трудової діяльності з комп'ютерною технікою. На основі результатів атестації робочих місць за умовами праці, виконаний аналіз показників світлового середовища. Встановлено, яка частина цих місць характеризуеться шкідливими умовами праці за фактором «освітлення». Визначено, які з параметрів світлового середовища найчастіше не відповідають вимогам нормативних документів. Зроблені дослідження впливу значущих чинників на втомлюваність операторів протягом робочої зміни. Як профілактику несприятливого впливу параметрів світлового середовища запропоновано комплекс захисних заходів з нормалізації показника «коефіцієнт пульсації освітленості» для аналізованих умов.
\end{abstract}

Ключові слова: персонал, світлове середовище, травматизм, функції зору, умови праці, стомлення.

Kuris Yuriy, Matyashev Dmitry Zaporizhzhia National University Matyasheva Oksana

Scientific and Methodological Center of Vocational Education in Zaporizhzhia region

\section{STUDYING THE INFLUENCE OF LIGHT ENVIRONMENT PARAMETERS ON HUMAN HEALTH}

Summary. It is known that the performance of any work for a long time is accompanied by body fatigue manifested in a decrease in the efficiency of the worker. Along with physical and mental work on his fatigue is significantly influenced by the production environment, that is, the conditions where the work is performed. Thus, the impact of lighting on human health is undeniable. Improper lighting poses a significant threat to the health of workers, and to a greater extent the negative impact of light environment factors are prone to operators of personal electronic computing machines. Therefore, the current issue is to study the parameters of sanitary and hygienic factors of the working environment in the workplaces of permanent stay of personnel in the process of work activities with computer equipment. Based on the results of the certification of workplaces for working conditions, performed an analysis of the indicators of artificial light environment on the following indicators: illumination of the working surface, direct glare, light pulsation factor. It was established what part of these places is characterized by harmful working conditions by the factor «lighting». It was determined which of the parameters of the light environment often do not meet the requirements of regulatory documents. Particular attention should be paid to the fact of total non-compliance with the norms of light pulsation at workplaces equipped with personal electronic computers (90\% of workplaces are characterized by exceeding the allowable values of the illumination pulsation factor). The influence of significant factors on operator fatigue during a work shift was investigated. Studies show that work in adverse hygienic conditions leads to the development of significantly more fatigue (in the absence of pulsation, the maximum values of visual fatigue are on average $11.7 \%$ lower) than the same work, but in normal conditions, so improving working conditions is an important factor in reducing fatigue. As a prevention of the adverse effects of the parameters of the light environment proposed a set of protective measures to normalize the indicator «illuminance pulsation factor» for the conditions under consideration.

Keywords: personnel, light environment, injuries, visual functions, working condi-tions, fatigue.

$\Pi^{2}$ остановка проблеми. Вплив світла на організм людини великий, оскільки від правильного освітлення залежить більшість біологічних процесів. За статистикою людина знаходиться на роботі близько 40 годин на тиждень. Таким чином, більшу частину світлового дня ми проводимо під штучним освітленням.

Відомо, що виконання будь-якої роботи протягом тривалого часу супроводжуеться стомленням організму, що проявляеться у зниженні працездатності робітника. Поряд з фізичною та розумовою роботою на його стомлення значно впливає і навколишне виробниче середовище, тобто умови, де виконують роботу. Таким чином, вплив освітлення на здоров'я людини незаперечне [1].
Аналіз останніх досліджень і публікацій. Над розв'язанням проблем, щодо негативного впливу світлового середовища на зорову праце спроможність та досліджень щодо створення комфортного світлового середовища на робочих місцях працювали багато вітчизняних вчених, серед яких О.В. Рабіч, Л.О. Чумак, І.В. Мещерякова, Л.М. Лаухіна, О.В. Березюк, Є.Г. Креготень [2].

Виділення не вирішених раніше частин загальної проблеми. Питання впливу фракторів, які виникають при використанні персональних EOM, на даний момент повністю не вивчені і тому вимагають поглиблених досліджень. Виникає необхідність додаткової оцінки впливу на персонал параметрів світлового середовища. 
Мета статті. Дослідити чинники, які суттево впливають на зорову стомлюваність персоналу, який працюе на ЕОМ, нормалізація яких дозволить забезпечити поліпшення умов пращі за показниками світлового середовища та надати рекомендації по їх усуненню.

Виклад основного матеріалу. Світло e необхідною умовою існування людини. Воно впливає на стан вищих психічних функцій і фрiзіологічні процеси в організмі. Гарне освітлення тонізуе, створюе гарний настрій, покращуе перебіг основних процесів вищої нервової діяльності. Найбільш значний вплив освітлення надае на фрункцію зору, а через неї на продуктивність праці. Раціональне освітлення відіграє важливу роль в профілактиці виробничого травматизму. Згідно зі статистикою в середньому при різних видах виробничої діяльності число нещасних випадків, пов'язаних 3 незадовільним освітленням, становить від 35 до 45\% від загальної кількості. При зорових роботах, що не вимагають високої точності, близько 1\% травм зі смертельним результатом відбуваеться через погане освітлення. Травматизм очей при таких роботах, безпосередньо пов'язаний з незадовільним освітленням, становить від $15 \%$ до $22 \%$. Причиною травматизму може бути як безпосередне погіршення видимості в робочій зоні, так і підвищене стомлення працівника внаслідок роботи в умовах незадовільного освітлення. Крім травматизму, несприятливі умови освітлення можуть викликати стомлення зорового аналізатора (при систематичному впливі - розвиток вад зору), знижувати працездатність, приводити до професійних захворювань. Можливість негативного впливу умов освітлення на працівників визначається цілою низкою чинників: відсутністю або недостатністю природного світла; зни-женою освітленістю; підвищеною яскравістю; підвищеної пульсацією освітленості; підвищеним рівнем ультрафіолетового випромінювання. 3 відсутністю природного світла пов'язане явище «світлового голодування». Світлове голодування - це стан організму, обумовлене дефіцитом ультрафріолетового випромінювання і виявляється в порушенні обміну речовин і зниження опірності організму. Крім того, тривала робота в приміщенні без природного світла може виявляти несприятливий психофрізіологічний вплив на персонал через відсутність зв'язку із зовнішнім світом, відчуття замкнутості простору. Недостатне освітлення робочого місця ускладнюе тривалу роботу, викликає підвищене стомлення і сприяе розвитку короткозорості. Занадто низькі рівні освітленості викликають апатію і сонливість, а в деяких випадках сприяють розвитку почуття тривоги. Тривале перебування в умовах недостатнього освітлення супроводжуються зниженням інтенсивності обміну речовин в організмі та ослабленням його реактивності. До таких наслідків призводить тривале перебування у світловому середовищі з обмеженим спектральним складом світла і монотонним режимом освітлення. Несприятливі умови для зорових робіт виникають не тільки при зниженій, а й надмірній освітленості. При дуже великій освітленості поверхні й високому коефіціенті відбиття в результаті підвищеної яскравості може виникати сліпуча дія, стан зорового дискомфорту. Запобіганню негативної дії підвищеної яскравості сприяе правильний устрій освітлювальних установок, дотримання необхідних рівнів освітленості. Крім освітленості на ефективність зорової роботи впливають також показники якості освітлення. Зокрема, робота в умовах освітлення, світло що пульсуе, знижуе працездатність органу зору, викликає підвищене стомлення, головний біль і т.д. Крім того, наявність в полі зору рухомих і обертових предметів, навіть при низьких значення коефіціента пульсації, може викликати стробоскопічний ефрект і призвести до виробничого травматизму. До шкідливих факторів штучного освітлення відноситься також підвищений рівень ультрафіолетового випромінювання, що відбуваеться при неправильному пристрої ультрафіолетових опромінюваних установок і при використанні газорозрядних ламп високого тиску, які мають у своєму спектрі значну частку ультрафріолетового випромінювання [3].

Широке впровадження персональних електронно-обчислювальних машин (ЕОМ) в виробничу діяльність призвело до появи нової медичної проблеми - так званого комп'ютерного зорового синдрому. У персоналу, що працюе на персональних ЕОМ виникае цілком обгрунтоване занепокоєння з приводу стану здоров'я як органів зору, так і організму в цілому. Використання пристроїв візуального відбиття інформації на робочих місцях стало, ймовірно, першим випадком, коли персонал почав висловлювати невдоволення з приводу того, що в робочих зонах занадто багато світла. Свої заяви вони підтверджували тим, що більшість персональних ЕОМ обладнано дисплеями 3 електронно-променевими трубками (ЕПТ), які мають вигнуті скляні поверхні, здатні добре відбивати світло. Такі пристрої, які називаються іноді «активними дисплеями», втрачають контрастність, якщо рівень навколишнього освітлення стає вище. Але спроби створити для цих робочих місць системи, що створюють невеликі рівні освітлення були визнані безперспективними виходячи з того факту, що більшість користувачів має також джерела інформації на паперових носіях, що, своєю чергою, вимагае підвищеного рівня освітлення. Таким чином, стає очевидно, що неправильне освітлення становить значну загрозу для здоров'я працівників, і більшою мірою негативному впливу фракторів світлового середовища схильні оператори персональних EOM.

Штучне освітлення виробничих приміщень слід оцінювати за такими показниками: освітленість робочої поверхні, прямий блиск, коефріціент пульсації освітленості. При оцінці робочих місць обладнаних персональними ЕОМ додатковими параметрами $е$ : яскравість, блиск, освітленість поверхні екрану, нерівномірність розподілу яскравості в поле зору користувача персональним EOM та візуальні параметри дисплея (яскравість білого поля, нерівномірність яскравості робочого поля, контрастність, для монохромного режиму, просторова й тимчасова нестабільність зображення) [4].

Інформація про фактичний стан умов праці за показниками світлового середовища представлена в табл. 1. 
Стан умов праці за показниками світлового середовища

Таблиця 1

\begin{tabular}{|c|c|c|c|c|c|c|c|c|}
\hline \multirow[b]{2}{*}{ Професійна назва роботи } & \multicolumn{2}{|c|}{$\begin{array}{c}\text { Освітленість } \\
\text { робочої } \\
\text { поверхні }\end{array}$} & \multicolumn{2}{|c|}{$\begin{array}{l}\text { Освітленість } \\
\text { екрана }\end{array}$} & \multicolumn{2}{|c|}{$\begin{array}{c}\text { Коефіціент } \\
\text { пульсації } \\
\text { освітленості } \\
\text { на робочій } \\
\text { поверхні }\end{array}$} & \multicolumn{2}{|c|}{ Яскравість } \\
\hline & 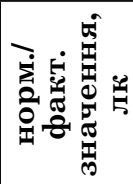 & 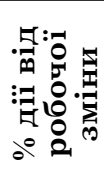 & 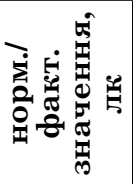 & 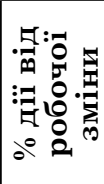 & 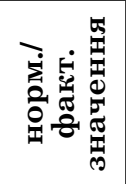 & 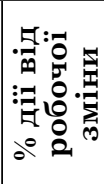 & 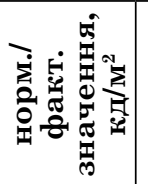 & 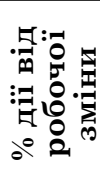 \\
\hline Начальник служби атомної елек & $400 / 310$ & 52 & $300 / 288$ & 52 & $20 / 29,9$ & 52 & $200 / 38$ & 52 \\
\hline Головний енергетик & $400 / 490$ & 51 & $300 / 190$ & 51 & $5 / 9,9$ & 51 & $200 / 39$ & 51 \\
\hline $\begin{array}{l}\text { Майстер з ремонту, налагодження, перевірки } \\
\text { та пуску устаткування атомних станщій }\end{array}$ & $500 / 356$ & 19 & $300 / 185$ & 19 & $5 / 30$ & 19 & $200 / 48$ & 19 \\
\hline Головний фрахівець з енергоблоків & $500 / 126$ & 50 & $300 / 130$ & 50 & $5 / 28,7$ & 50 & $200 / 34$ & 50 \\
\hline Інженер служби підстанцій & $400 / 301$ & 52 & $300 / 286$ & 52 & $20 / 32,1$ & 52 & $200 / 28$ & 50 \\
\hline Інженер з технічної діагностики & $500 / 180$ & 50 & $300 / 180$ & 50 & $5 / 22,3$ & 50 & $200 / 56$ & 50 \\
\hline Технік-енергетик & $500 / 330$ & 51 & $300 / 180$ & 51 & $5 / 30$ & 51 & $200 / 36$ & 51 \\
\hline $\begin{array}{l}\text { лектромонтер з обслуговування } \\
\text { лектроустановок }\end{array}$ & $400 / 410$ & 12 & $300 / 170$ & 12 & $20 / 21,4$ & 12 & $200 / 54$ & 12 \\
\hline реакторг & $500 / 690$ & 95 & $300 / 380$ & 95 & $20 / 31$ & 95 & $200 / 290$ & 95 \\
\hline
\end{tabular}

Персональними електронно-обчислювальними машинами обладнано $65 \%$ робочих місць, i, безсумнівно, кількість таких місць буде з часом тільки збільшуватися, що говорить про необхідність прийняття ефективних заходів, спрямованих на нормалізацію параметрів світлового середовища.

Варто відзначити, що всі робочі місця персоналу електричних підстанцій в даний час обладнані персональними $\mathrm{EOM}$, і хоча час роботи зазначеного персоналу на комп'ютері не складає 100\%, на ці місця поширюються більш строгі вимоги до освітлення.

Виробнича діяльність персоналу електричних підстанцій пов'язана зі значною психологічною напруженістю, яка $е$ наслідком високої відповідальності виконуваних робіт, оскільки помилкові дії цих працівників можуть привести до серйозних наслідків, до збоїв в роботі великих енергосистем.

Особливої уваги заслуговуе факт тотального недотримання норм, щодо пульсації освітленості на робочих місцях, обладнаних персональними EOM (90\% робочих місць характеризуються перевищенням допустимих значень коефіцієнта пульсації освітленості).

Ступінь зорового стомлення $є$ постійною величиною, для значної більшості видів робіт типовим $\varepsilon$ наростання стомлення, тому були проведені дослідження впливу пульсації освітленості на зміну зорового стомлення операторів персональної EOM впродовж робочої зміни. Так як людина не здатна візуально оцінити рівень пульсації освітленості, їм не повідомлялося його значення, що дозволило отримати їх суб'єктивну оцінку умов освітлення. Параметри штучного освітлення (освітленість робочої поверхні, екрана монітора, яскравість, нерівномірність розподілу яскравості та ін.) для різних експериментів підтримувалися на однакових рівнях і відповідали вимогам нормативних документів [5].

Для оцінки рівня зорової стомлюваності використовувався монітор з електронно-променевою трубкою як найбільш часто вживаний. Умови до- сліду відповідали роботі на комп'ютері середньої інтенсивності. Оцінка рівня зорового стомлення проводилася кожні 30 хвилин, в перервах між вимірами виконувалися завдання, які потребували переключення уваги з екрану персональної EOM на робочу поверхню. Результати дослідів представлені на рисунку 1.

Якщо на людини не впливае такий істотний чинник як пульсація освітленості, організм протягом тривалого часу здатний компенсувати втому, яка розвиваеться. Згідно графіка, при відсутності пульсації освітленості, зорове стомлення зберігаеться приблизно на однаковому рівні до обідньої перерви і лише до кінця зміни трохи зростае. При $20 \%$ пульсації освітленості до кінця зміни оператори скаржилися на труднощі зосередження уваги, втому і неприемні відчуття в очах, що, ймовірно, можна пояснити несприятливим впливом зазначеного фактору. Як показують дослідження, робота в несприятливих санітарно-гігіенічних умовах призводить до розвитку значно більшого стомлення (при відсутності пульсації максимальні значення зорового стомлення в середньому на $11,7 \%$ нижче), ніж та ж робота, але в нормальних умовах, тому поліпшення умов праці є важливим фактором зниження втоми.

Обмеження глибини пульсації освітленості може бути виконано різними способами:

- включенням ламп в світильниках з люмінесцентними лампами за схемами, які забезпечують живлення частині ламп, що відстають, а частині ламп - випереджальним струмом;

- почерговим приеднанням сусідніх світильників в ряду - рідше сусідніх рядів - до різних фаз мережі;

- установкою в одній точці двох або трьох світильників різних фраз (лампи типів ДРЛ (дугова ртутна люмінесцентна лампа) і МГЛ (металогалогенні лампи));

- живлення різних ламп в багатолампових люмінесцентних світильниках від різних фаз;

- високочастотним живленням джерел світла. 


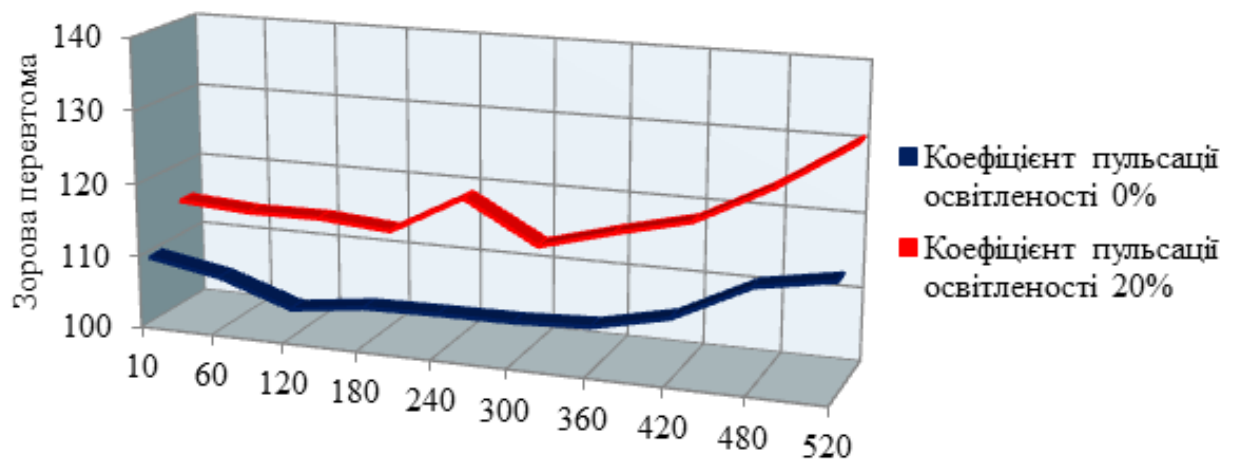

Тривалість робочоі̄ зміни, хв

Рис. 1. Залежність зорової перевтоми від коефіціента пульсації освіт-леності

Висновки і пропозиції. Раціональне освітлення робочого місця е одним 3 найважливіших факторів, які впливають на ефективність трудової діяльності персоналу та попереджають травматизм й професійні захворювання. Правильно організоване освітлення створюе сприятливі умови праці, підвищуе працездатність і продуктивність праці. Саме тому дотримання вимог па- раметрів освітлення займає досить важливу роль в діяльності будь-якого підприемства. Одним із дієвих способів усунення впливу пульсації освітленості на працівників $є$ високочастотне живлення джерел світла. Це здійснюеться шляхом застосування в світильниках з газорозрядними лампами електронних високочастотних пускорегулюючих апаратів.

\section{Список літератури:}

1. Куріс Ю.В., Тарасов В.К., Матяшева О.Б., Беренда Н.В. Дослідження впливу шкідливих чинників на працездатність персоналу, що обслуговуе комп'ютерну техніку. Металургія : Наукові праці Інженерного інституту Запорізького національного університету. 2017. № 1(37). С. 137-141.

2. Рабіч О.В., Чумак Л.О., Мещерякова І.В. Аналіз зміни умов праці робочих місць при модернізації виробництва. Геотехнічна механіка. Міжвідомчий збірник наукових праць. Головний редактор академік НАН України А.Ф. Булат. Випуск 128. Дніпро, 2016. С. 31-45.

3. Третьяков О.В., Зацарний В.В., Безсонний В.Л. Охорона пращі : навчальний посібник. Київ : Знання, 2010. 167 с.

4. ДБН В.2.5-28-2006. Природне і штучне освітлення. Мінбуд України : Київ, 2006. URL: https://www.sunpower.ua/ cp37498-dbn-v25-28-2006-prirodne-shtuchne-osvtlennya.html (дата звернення: 26.05.2021).

5. ДСНтаП «Гігіенічна класифікація праці за показниками шкідливості та небезпечності факторів виробничого середовища, важкості та напруженості трудового процесу» : Затверджено Наказом Міністерства охорони здоров'я України від 08.04.2014 № 248. URL: https://www.zakon.rada.gov.ua/laws/show/z0472-14 (дата звернення: 26.05.2021).

\section{References:}

1. Kuris Y.V., Tarasov V.K., Matyasheva O.B., Berenda N.V. (2017) Doslidzhennya vplyvu shkidlyvyx chynnykiv na pracezdatnist personalu, shho obslugovuye kompyuternu texniku [Investigation of the influence of adverse factors on the productivity of the personnel who maintains computer technology]. Metallurgy, vol. 1(37), pp. 137-141.

2. Rabich H.V., Chumak L.A., Mescheryakova I.V. (2016) Analiz zminy umov praci robochyx miscz pry modernizaciyi vyrobnycztva [Analysis of changes in workplace conditions during modernization of production]. Geotechnical mechanics, vol. 128 , pp. 31-45.

3. Tretyakov A.V., Zatsarniy V.V., Bezsonniy V.K. (2010) Okhorona pratsi: navchalny iosibnyk [Labour protection: train aid]. Kiyv: Knowledge.

4. Minbuild of Ukraine (2006) «DBN V.2.5-28-2006. Natural and artificial lighting». Available at: https://www.sunpower.ua/cp37498-dbn-v25-28-2006-prirodne-shtuchne-osvtlennya.html

5. Ministry of Health of Ukraine (2014) DSNtaP «Hygienic classification of work in terms of hazard and danger environment factors, severity and intensity of the work process». Available at: https://www.zakon.rada.gov.ua/ laws/show/z0472-14 